\title{
Valerian (Valeriana officinalis L.) tolerance to some post-emergence herbicides
}

\author{
Nadia Monjezi, Jamshid Razmjo, Hassan Karimmojeni*
}

Department of Agronomy and Plant Breeding, College of Agriculture, Isfahan University of Technology, Isfahan, 84156-83111, Iran

Received: April 21, 2015

Accepted: November 9, 2015

\begin{abstract}
Valerian (Valeriana officinalis L.) is a medicinal plant, but its cultivation is restricted by weed competition. Therefore, three rates $(0.75 \mathrm{X}, 1 \mathrm{X}$, and $1.25 \mathrm{X}$, where $\mathrm{X}$ is equal to the recommended dose of haloxyfop- $\mathrm{R}$ (methyl ester), sethoxydim, oxadiargyl, bentazon, oxadiazon, and oxyfluorfen) were applied at the 3-4 leaf stages to valerian plants. This application was done to select the herbicide type and rate for post-controlling broadleaf and grasses weeds in this species. Herbicide injury, Soil-Plant Analyses Development (SPAD) reading, number of leaves per plant, stem diameter, and fresh and dry weights were determined 10, 20, and 30 days after herbicide application. Oxyfluorfen application caused the most herbicide injury followed by bentazon. Injury increased as the rate and the days after application increased. Oxadiazon only caused significant damage 30 days after application under all three rates. Other treatments showed no marked injuries under any rate or date after application, as compared with the control. Effects on other measured traits depended on the trait, herbicide, and herbicide rate. The highest SPAD, leaf number, shoot diameter, fresh weight and dry weight, was recorded under application of $30 \mathrm{mg}$ a.i. $\cdot \mathrm{kg}^{-1}$ soil oxadiargyl and $90 \mathrm{mg}$ a.i. $\cdot \mathrm{kg}^{-1}$ soil oxadiazon, $81 \mathrm{mg}$ a.i. $\cdot \mathrm{kg}^{-1} \mathrm{soil}$ haloxyfop-R, $37.5 \mathrm{mg}$ a.i. $\cdot \mathrm{kg}^{-1}$ soil oxadiargyl, $22.5 \mathrm{mg}$ a.i. $\cdot \mathrm{kg}^{-1}$ soil oxadiargyl, $81 \mathrm{mg}$ a.i. $\cdot \mathrm{kg}^{-1}$ soil haloxyfop-R, and $81 \mathrm{mg}$ a.i. $\cdot \mathrm{kg}^{-1}$ soil haloxyfop-R, respectively. To sum up, the results showed that sethoxydim, oxadiargyl, and haloxyfop-R produced no significant symptoms of phytotoxicity or reduction of measured traits. This means that oxadiargyl, haloxyfop- $R$, and sethoxydim may be used safely for weed control of valerian at the rates used in this experiment under similar conditions.
\end{abstract}

Key words: accase inhibitor herbicide, medicinal plant, photosynthesis inhibitor herbicides, selective weed control

\section{Introduction}

Valerian (Valeriana officinalis L.) (Valerianaceae) is a perennial flowering medicinal plant native to Europe and Asia. Weed control of valerian is one of the main limiting factors for production of this species especially when valerian is being established. Use of herbicides in weed control of some medicinal plants has been reported. Qasem and Foy (2006) applied pre-planting and post-planting of oxyfluorfen and oxadiazon to Origanum syriacum L., and reported that both herbicides were highly selective and effective for weed control of this species. Zheljazko et al. (2006) showed that application of pendimethalin and metribuzin alone or in combination were safe for weed control of Silybum marianum L. Forcella et al. (2012) tested the tolerance of Calendula officinalis L. to desmedipham and phenmedipham postemergence herbicides, and showed that this species was tolerant to both herbicides. Yousefi and Rahimi (2014) applied trifluralin and pendimethalin herbicides to Foeniculum vulgare Mill. and reported that both herbicides provided some weed control without any injury to the crop, but pendimethalin was more effective. Yet, there is little information on the tolerance of valerian to the application of herbicides. There have been a number of herbicides found in Poland that could be used for weed control of valerian, after sowing valerian seedlings and after growing weed species. Studies showed that foliar application of the haloxyfop-R herbicide after using pendimethalin herbicide and by using mechanical implement methods, caused maximum root and rhizome productivity. It also caused a low degree of damage to this herbal plant. Also, mechanical implement methods decreased the amount of weeds in crops (Kwiatkowski 2010). Pank et al. (1980) state that the application of chlorpropham controlled weeds in valerian and that this herbicide did not have an effect on the quality and quantity of valerian.

Thus, information regarding both crop tolerance and sensitivity to an herbicide are required for chemical weed control in this species. If tolerance is adequate, herbicides will then provide management of grass and broadleaf weeds. The objective of this study was to determine the tolerance of valerian to the post-planting application of bentazon (Basagran), oxadiargyl (Top Star), oxadiazon (Ronstar), oxyfluorfen (Goal), haloxyfop-R (methyl ester) (Gallant Duper), and sethoxydim (Nabo-S).

\section{Materials and Methods}

This experiment was conducted in the research greenhouse, located in the Faculty of Agriculture, Isfahan 
University of Technology, in 2014. The experiment was performed as factorial, based on the randomised complete block design with 19 treatments and 3 replications. Valerian plant seedlings, in compound media (50\% cocopeat and $10 \%$ perlite and $40 \%$ soil) were prepared and the seedlings at the 2-3 leaf stages were transferred to pots. The pots had a $15 \mathrm{~cm}$ diameter and $20 \mathrm{~cm}$ height. Pots were irrigated every 3 days, during the growing season, and the plants before application of herbicides, were thinned to 3 plants per pot.

In this experiment, haloxyfop-R (methyl ester) (Gallant Super) and sethoxydim (Nabo-S) as graminicide and broadleaf herbicides including oxadiargyl (Top Star), bentazon (Basagran), oxadiazon (Ronstar), and oxyfluorfen (Goal), as well as a control (not-sprayed), were used.

The herbicides were applied at three different doses: 0.75X (D1), 1X (D2), and 1.25X (D3) where X is equal to the recommended dose. Recommended dosages included: haloxyfop-R (methyl ester) - $108 \mathrm{mg}$ a.i. $\cdot \mathrm{kg}^{-1}$ soil (10.8\% EC), sethoxydim $-125 \mathrm{mg}$ a.i. $\cdot \mathrm{kg}^{-1}$ soil (12.5\% OEC), oxadiargyl $-30 \mathrm{mg}$ a.i. $\cdot \mathrm{kg}^{-1}$ soil ( $\%$ EC), bentazon $-480 \mathrm{mg}$ a.i. $\cdot \mathrm{kg}^{-1}$ soil $(48 \% \mathrm{SL})$, oxadiazon $-120 \mathrm{mg}$ a.i. $\cdot \mathrm{kg}^{-1}$ soil (12\% EC), and oxyfluorfen $240 \mathrm{mg}$ a.i. $\cdot \mathrm{kg}^{-1}$ soil (24\% EC) (Table 1).

Herbicides were applied, at the beginning growth stage of the crop, at the 3-4 leaf stages of the valerian plant. After the herbicide treatment, plants were checked for symptoms (Stunting, chlorosis, and necrosis). Plants were compared to the control by visual ratings provided by the Weed Research Society of Europe (EWRS). Damage to the product was defined in three steps: 10, 20, and 30 days after treatment (DAT) using a scale of $0-100 \%$, where a score of 0 means no visible damage to the plant, and a score of 100 means plant death. The leaf Soil-Plant
Analyses Development (SPAD) index, using a chlorophyll meter for the same leaves, was measured and its average was recorded for each pot. In the 6-7 leaf stages, the fresh and dry weight of the shoots were measured. To do the measuring, plants were harvested from the above soil level, and dry matter accumulation was determined by drying the plant shoot material for $48 \mathrm{~h}$ in an oven at $75^{\circ} \mathrm{C}$. Other traits measured included stem diameter $(\mathrm{cm})$, and number of leaves per plant.

\section{Statistical analysis}

Before analysing the data, the assumption of a homogeneous variation was tested. Finally, the analysis of variance for the data collected for each attribute, using the statistical program (Statistics) was done. If the analysis of variance indicated statistically significant differences, the means were compared using Fisher's protected least significant difference test $(\mathrm{p}>0.05)$.

\section{Results and Discussion}

\section{Crop injury}

Herbicide application had a significant effect on crop injury 10,20, and 30 days after the application of the herbicide (Table 2). Oxyfluorfen caused the highest injury followed by bentazon under D1, D2, and D3 (D1 = 0.75X, D2 = $=\mathrm{X}$, and D3 $=1.25 \mathrm{X}$. Injury appeared over time and became more pronounced (Table 3). Oxadiazon application under D3 only, showed significant injury. The other herbicides had no marked injury under any date after application.

Table 1. Herbicides and herbicide rates used in the experiment

\begin{tabular}{lccr}
\hline \multirow{2}{*}{ Herbicides } & \multicolumn{3}{c}{ Proportion of labeled use rate } \\
\cline { 2 - 4 } & $0.75 X(\mathrm{D} 1)$ & 1X (D2) & 1.25X (D3) \\
\hline Bentazon & 360.0 & 480 & 300.0 \\
Oxadiargyl & 22.5 & 120 & 37.5 \\
Oxadiazon & 90.0 & 240 & 300.0 \\
Oxyfluorfen & 180.0 & 108 & 150.0 \\
Haloxyfop-R (methyl ester) & 81.0 & 125 & 135.0 \\
Sethoxydim & 93.75 & & 156.25 \\
\hline
\end{tabular}

Rates of herbicides are presented in $\left(\mathrm{mg}\right.$ a.i. $\cdot \mathrm{kg}^{-1}$ soil $)$

Table 2. Analysis of variance results for injury score of Valeriana officinalis 10, 20, and 30 days after treatment (DAT) with herbicides

\begin{tabular}{|c|c|c|c|c|}
\hline \multirow{2}{*}{ Source of variation } & \multirow{2}{*}{$\mathrm{df}$} & \multicolumn{3}{|c|}{$\%$ Injury $^{\mathrm{a}}(\mathrm{DAT})$} \\
\hline & & 10 DAT & 20 DAT & 30 DAT \\
\hline Herbicide & 6 & $5,131 \cdot 26^{* * *}$ & $6,388.42^{* * *}$ & $7,574.24^{* * *}$ \\
\hline Dose & 2 & $153.16^{* * *}$ & $63.58^{* *}$ & $90.21^{*}$ \\
\hline Herbicide $\times$ dose & 12 & $101.86^{* * *}$ & $33.5^{* * *}$ & 16.84 \\
\hline Error & 40 & 2.34 & 8.83 & 19.27 \\
\hline $\mathrm{CV}$ & - & 14.21 & 21.08 & 27.30 \\
\hline
\end{tabular}

${ }^{*}$ significant at $\mathrm{p} \leq 0.05 ;{ }^{* *}$ significant at $\mathrm{p} \leq 0.01 ;{ }^{* * *}$ significant at $\mathrm{p} \leq 0.001$

${ }^{\mathrm{a}}$ crop injury score using a scale of 0-100 (\%) where $0 \%$ represents no injury to plants and $100 \%$ means dead plants

$\mathrm{df}$ - degrees of freedom; CV - coefficient of variation 
Table 3. Effect of herbicide on the injury score of Valeriana officinalis 10, 20, and 30 days after treatment (DAT)

\begin{tabular}{|c|c|c|c|}
\hline \multirow{2}{*}{ Herbicides } & \multicolumn{3}{|c|}{ \% Injurya (DAT) } \\
\hline & $10 \mathrm{DAT}$ & $20 \mathrm{DAT}$ & 30 DAT \\
\hline The control & $1.0 \mathrm{c}$ & $1.0 \mathrm{c}$ & $1.0 \mathrm{~d}$ \\
\hline Bentazon & $3.1 \mathrm{~b}$ & $16.4 \mathrm{~b}$ & $14.3 \mathrm{~b}$ \\
\hline Oxadiargyl & $2.4 \mathrm{bc}$ & $2.0 \mathrm{c}$ & $1.9 \mathrm{~d}$ \\
\hline Oxadiazon & $1.5 \mathrm{c}$ & $2.5 \mathrm{c}$ & $8.3 \mathrm{c}$ \\
\hline Oxyfluorfen & $64.8 \mathrm{a}$ & $73.2 \mathrm{a}$ & $81.0 \mathrm{a}$ \\
\hline Haloxyfop-R (methyl ester) & $1.0 \mathrm{c}$ & $2.1 \mathrm{c}$ & $2.0 \mathrm{~d}$ \\
\hline Sethoxydim & $1.3 \mathrm{c}$ & $1.3 \mathrm{c}$ & $4.0 \mathrm{~d}$ \\
\hline LSD & 1.45 & 2.83 & 4.2 \\
\hline
\end{tabular}

Treatments with the same letter in a column are not significantly different at $\mathrm{p}<0.05$ as assessed by the LSD test ${ }^{a}$ crop injury score using a scale of 0-100 (\%) where $0 \%$ represents no injury plants and $100 \%$ means dead plants

Table 4. Effect of various doses of herbicide on the injury score of Valeriana officinalis 10, 20, and 30 days after treatment (DAT)

\begin{tabular}{|c|c|c|c|}
\hline \multirow{2}{*}{$\begin{array}{l}\text { Rate of application } \\
{\left[\mathrm{mg} \text { a.i } \cdot \mathrm{kg}^{-1}\right]}\end{array}$} & \multicolumn{3}{|c|}{ \% Injury ${ }^{a}(\mathrm{DAT})$} \\
\hline & $10 \mathrm{DAT}$ & 20 DAT & $30 \mathrm{DAT}$ \\
\hline $0.75 X(\mathrm{D} 1)$ & $8.2 \mathrm{c}$ & $12.4 \mathrm{~b}$ & $14.0 \mathrm{~b}$ \\
\hline $1 X(\mathrm{D} 2)$ & $10.5 \mathrm{~b}$ & $14.0 \mathrm{~b}$ & $16.0 \mathrm{ab}$ \\
\hline $1.25 X(\mathrm{D} 3)$ & $13.6 \mathrm{a}$ & $15.9 \mathrm{a}$ & $18.2 \mathrm{a}$ \\
\hline LSD & 0.95 & 1.85 & 2.7 \\
\hline
\end{tabular}

Treatments with the same letter in a column are not significantly different at $\mathrm{p}<0.05$ as assessed by the LSD test ${ }^{a}$ crop injury score using a scale of 0-100 (\%) where 0\% represents no injury plants and 100\% means dead plants

The percent injury increased with an increased rate and became more pronounced over time (Table 4). Oxyfluorfen herbicide injury increased the most, followed by bentazon as the rate increased, and became more pronounced over time (Table 5). Marked injury was noted after bentazon had been applied at 20 and 30 days, under all three rates. Oxadiazon only caused significant damage at 30 days after application under all three rates. The other treatments showed no marked injuries under any rate or date after application, as compared with the control (Table 5).

Bentazon is a benzothiadiazole post-emergence herbicide that can control several broadleaf weed species (Vencill 2002). Bentazon inhibits the electron flow in the photosynthesis pathway (Mine et al. 1975). Soltani et al. (2008) reported that application of $840 \mathrm{~g} \cdot \mathrm{ha}^{-1}$ bentazon once caused no injury in pinto bean, but when it was applied twice, it caused a $4 \%$ injury after 7 days, but no significant injury at 14 or 28 DAT. Beuer et al. (1995) also reported no marked injury in pinto bean 7 and 14 days after treatment with 420,840 , and 1,680 $\mathrm{g} \cdot \mathrm{ha}^{-1}$ bentazon. In contrast, Soltani et al. (2006) reported 30 to $33 \%$ plant injury in Adzuki bean when bentazon was applied at 1,080 $\mathrm{g} \cdot \mathrm{ha}^{-1}$. The visual injury range to sweet corn from the bentazon application was 0 to $69 \%$, depending on the cultivar and rate of application (Diebold et al. 2004). Contrasting results could be due to genotype, application rate, plant growth, and the amount of DAT of the herbicide.

Sethoxydim and haloxyfop inhibit acetyl-CoA (ACC) carboxylase that is needed for fatty acid synthesis and the subsequent production of phospholipids which is needed for plant cell membrane. These herbicides control an- nual and perennial grass species (Vencill 2002; Pavlivna et al. 2014). Their selectivity for grass control depends on ACCase susceptibility in the grass species. Normally, dicotyledonous contains an ACCase less susceptible to inhibition by such herbicides, when compared to the enzyme in grasses (Stoltenberg et al.1989). Sethoxydim and haloxyfop-R injuries were not significantly different from that of the control under any rate or day after application. These results were expected since both herbicides are used for controlling grass weeds in dicotyledonous crops. In line with our results, Soltani et al. (2006) reported that sethoxydim at 500 and $1,000 \mathrm{~g} \cdot \mathrm{ha}^{-1}$ caused between 0 to only $4 \%$ injury at lower rates of use and 1 to $5 \%$ at higher rates, in Adzuki bean. Visual injury increased with an increasing rate of herbicide use but the rate was reduced over time. In contrast, Al-Khatib et al. (2003) reported that injury to grain sorghum depend on the cultivar, year, and rate of sethoxydim application, and the injury was from 0 to $99 \%$.

Oxadiazon inhibits the Hill reaction of photosynthesis. Oxadiazon is a selective pre-emergence herbicide for controlling annual grasses and broad leaf weeds. Our results showed that oxadiazon application had no marked injuries to valerian 10 to $20 \mathrm{DAT}$ at any rate, but caused 6.1 to $11.3 \%$ injury, 30 DAT (Table 5). That was expected since this herbicide is a long-lasting performance herbicide. Brecke et al. (2010) applied oxadiazon to turfgrass species prior to or following turfgrass sprigging. The herbicide did not cause any injury, but caused serious injury at sprigging. Lamont and Spohr (1988) showed that application of oxadiazon produced no injury on ornamental plants. 
Table 5. Interactions of herbicides and their doses on the injury score of Valeriana officinalis 10, 20, and 30 days after treatment (DAT)

\begin{tabular}{|c|c|c|c|c|}
\hline \multirow{2}{*}{ Treatment } & \multirow{2}{*}{$\begin{array}{l}\text { Rate of application } \\
\quad\left[\mathrm{mg} \text { a.i. } \cdot \mathrm{kg}^{-1}\right]\end{array}$} & \multicolumn{3}{|c|}{$\%$ Injury (DAT) } \\
\hline & & $10 \mathrm{DAT}$ & $20 \mathrm{DAT}$ & 30 DAT \\
\hline The control & - & $1.0 \mathrm{e}$ & $1.0 \mathrm{e}$ & $1.0 \mathrm{e}$ \\
\hline \multirow[t]{3}{*}{ Bentazon } & D1 & $1.0 \mathrm{e}$ & $14.8 \mathrm{~d}$ & $10.8 \mathrm{~cd}$ \\
\hline & D2 & $3.1 \mathrm{de}$ & $16.6 \mathrm{~d}$ & $15.3 \mathrm{c}$ \\
\hline & D3 & $3.5 \mathrm{de}$ & $17.8 \mathrm{~d}$ & $16.6 \mathrm{c}$ \\
\hline \multirow[t]{3}{*}{ Oxadiargyl } & D1 & $1.3 \mathrm{e}$ & $1.6 \mathrm{e}$ & $1.3 \mathrm{e}$ \\
\hline & D2 & $1.6 \mathrm{e}$ & $1.6 \mathrm{e}$ & $1.6 \mathrm{e}$ \\
\hline & D3 & $4.3 \mathrm{~d}$ & $2.6 \mathrm{e}$ & $2.6 \mathrm{e}$ \\
\hline \multirow[t]{3}{*}{ Oxadiazon } & D1 & $1.0 \mathrm{e}$ & $2.3 \mathrm{e}$ & $6.1 \mathrm{de}$ \\
\hline & D2 & $1.0 \mathrm{e}$ & $2.3 \mathrm{e}$ & 7.5 de \\
\hline & D3 & $2.6 \mathrm{de}$ & $3.0 \mathrm{e}$ & $11.3 \mathrm{~cd}$ \\
\hline \multirow[t]{3}{*}{ Oxyfluorfen } & D1 & $49.3 \mathrm{c}$ & $64.3 \mathrm{a}$ & $74.3 \mathrm{~b}$ \\
\hline & D2 & $64.3 \mathrm{~b}$ & $72.6 \mathrm{~b}$ & $81.0 \mathrm{ab}$ \\
\hline & D3 & $81.0 \mathrm{a}$ & $82.6 \mathrm{a}$ & $87.6 \mathrm{a}$ \\
\hline \multirow[t]{3}{*}{ Haloxyfop-R (methyl ester) } & D1 & $1.0 \mathrm{e}$ & $1.6 \mathrm{e}$ & $1.3 \mathrm{e}$ \\
\hline & D2 & $1.0 \mathrm{e}$ & $2.3 \mathrm{e}$ & $2.3 \mathrm{e}$ \\
\hline & D3 & $1.0 \mathrm{e}$ & $2.3 \mathrm{e}$ & $2.3 \mathrm{e}$ \\
\hline \multirow[t]{3}{*}{ Sethoxydim } & D1 & $1.0 \mathrm{e}$ & $1.0 \mathrm{e}$ & $3.3 \mathrm{e}$ \\
\hline & D2 & $1.3 \mathrm{e}$ & $1.3 \mathrm{e}$ & $3.1 \mathrm{e}$ \\
\hline & D3 & $1.6 \mathrm{e}$ & $1.6 \mathrm{e}$ & $5.6 \mathrm{de}$ \\
\hline LSD & - & 2.52 & 4.9 & 7.24 \\
\hline
\end{tabular}

Treatments with the same letter in a column are not significantly different at $\mathrm{p}<0.05$ as assessed by the LSD test

Table 6. Analysis of variance results for chlorophyll content, leaf number, plant height, shoot diameter, shoot fresh and dry weight of Valeriana officinalis after treatment with herbicides

\begin{tabular}{lcccccc}
\hline Source of variation & df & $\begin{array}{c}\text { Chlorophyll } \\
\text { content }\end{array}$ & $\begin{array}{c}\text { Leaf } \\
\text { number }\end{array}$ & $\begin{array}{c}\text { Shoot } \\
\text { diameter }\end{array}$ & $\begin{array}{c}\text { Shoot fresh } \\
\text { weight }\end{array}$ & $\begin{array}{c}\text { Shoot dry } \\
\text { weight }\end{array}$ \\
\hline Herbicide & 6 & $50.37^{* * *}$ & $1.72^{*}$ & $0.69^{* *}$ & $78.65^{* * *}$ & $0.83^{* * *}$ \\
Dose & 2 & 20.45 & 0.12 & 0.33 & $40.62^{* * *}$ & $0.31^{* * *}$ \\
Herbicide $\times$ dose & 12 & 10.80 & 0.53 & 0.24 & $3.47^{* * *}$ & $0.02^{* *}$ \\
Error & 40 & 6.6 & 0.62 & 0.18 & 0.55 & 0.007 \\
CV & - & 12.56 & 15.95 & 21.63 & 9.59 & 10.02 \\
\hline
\end{tabular}

${ }^{*}$ significant at $\mathrm{p} \leq 0.05 ;{ }^{* *}$ significant at $\mathrm{p} \leq 0.01 ;{ }^{* * *}$ significant at $\mathrm{p} \leq 0.001$

$\mathrm{df}$ - degrees of freedom; CV - coefficient of variation

Oxadiargyl herbicide inhibits the enzyme which is in the pigment synthesis pathway (Boger and Wakabayashi 1995). Application of oxadiargyl resulted in no marked injury to valerian at any rate or day after application. In contrast, at least in part, Alebrahim et al. (2012) reported that application of oxadiargyl caused 1 to $23 \%$ injury to potato, but three weeks after application the plants had recovered. Nethra and Jagannath (2011) showed that maize and sunflower injuries increased when oxadiargyl concentrations were increased.

Oxyfluorfen kills broadleaf plants by destroying cell membranes within the leaves and shoots. Oxyfluorfen 10, 20 , and 30 DAT caused 49.3 to $81.0 \%, 64.3$ to $82.6 \%$, and 74.3 to $87.6 \%$ injuries to the crop, respectively (Table 5). Loken et al. (2010) reported that oxyfluofen application injured onion about 15\%. While Norsworthy et al. (2007), reported that application of oxyfluorfen $\left(134 \mathrm{~g} \cdot \mathrm{ha}^{-1}\right)$ only caused 3\% injury in green onion.

\section{Chlorophyll content and morpho-physiological traits}

Herbicide application had a significant effect on the SPAD reading, number of leaves per plant, stem diameter, and fresh and dry weights (Table 6). On average, all of the herbicides reduced fresh and dry weights, stem diameter, and the SPAD reading, but increased or did not affect leaf number (Table 7). The following were not affected: chlorophyll content, reduced fresh weight and dry weight, and leaf number and shoot diameter, when the herbicide rate was increased (Table 8). However, these effects depend on the measured trait. Herbicide and herbicide rate, and the highest chlorophyll content, leaf number, shoot diameter, fresh weight and dry weight were recorded under application of $30 \mathrm{mg}$ a.i. $\cdot \mathrm{kg}^{-1}$ soil oxadiargyl and $90 \mathrm{mg}$ a.i. $\cdot \mathrm{kg}^{-1}$ soil oxadiazon, $81 \mathrm{mg}$ a.i. $\cdot \mathrm{kg}^{-1}$ soil haloxyfop$\mathrm{R}, 37.5 \mathrm{mg}$ a.i. $\cdot \mathrm{kg}^{-1}$ soil oxadiargyl, $22.5 \mathrm{mg}$ a.i. $\cdot \mathrm{kg}^{-1}$ soil oxadiargyl, $81 \mathrm{mg}$ a.i. $\cdot \mathrm{kg}^{-1}$ soil haloxyfop-R and $81 \mathrm{mg}$ a.i. $\cdot \mathrm{kg}^{-1}$ soil haloxyfop-R, respectively (Table 9 ). 
Table 7. Effect of herbicides on chlorophyll content, leaf number, plant height, shoot diameter, shoot fresh and dry weight of Valeriana officinalis

\begin{tabular}{lccccc}
\hline \multicolumn{1}{c}{ Herbicides } & $\begin{array}{c}\text { Chlorophyll content } \\
\text { [spad value] }\end{array}$ & $\begin{array}{c}\text { Leaf number } \\
\text { [plant] }\end{array}$ & $\begin{array}{c}\text { Shoot diameter } \\
{[\mathrm{cm}]}\end{array}$ & $\begin{array}{c}\text { Shoot fresh weight } \\
{[\mathrm{g}]}\end{array}$ & $\begin{array}{c}\text { Shoot dry weight } \\
{[\mathrm{g}]}\end{array}$ \\
\hline The control & $23.5 \mathrm{a}$ & $4.5 \mathrm{bc}$ & $2.4 \mathrm{a}$ & $10.5 \mathrm{a}$ & $1.0 \mathrm{a}$ \\
Bentazon & $19.9 \mathrm{~b}$ & $4.2 \mathrm{c}$ & $1.94 \mathrm{bcd}$ & $5.2 \mathrm{~d}$ & $0.51 \mathrm{c}$ \\
Oxadiargyl & $21.2 \mathrm{ab}$ & $4.8 \mathrm{abc}$ & $2.10 \mathrm{ab}$ & $9.1 \mathrm{~b}$ & $0.98 \mathrm{a}$ \\
Oxadiazon & $21.3 \mathrm{ab}$ & $5.2 \mathrm{a}$ & $1.75 \mathrm{~cd}$ & $8.3 \mathrm{c}$ & $0.87 \mathrm{~b}$ \\
Oxyfluorfen & $15.7 \mathrm{c}$ & $4.3 \mathrm{c}$ & $1.58 \mathrm{~d}$ & $2.2 \mathrm{e}$ & $0.23 \mathrm{~d}$ \\
Haloxyfop-R & $21.1 \mathrm{ab}$ & $5.6 \mathrm{a}$ & $1.95 \mathrm{bcd}$ & $9.9 \mathrm{a}$ & $1.0 \mathrm{a}$ \\
(methyl ester) & $20.4 \mathrm{~b}$ & $5.2 \mathrm{ab}$ & $1.96 \mathrm{bc}$ & $8.8 \mathrm{bc}$ & $0.9 \mathrm{~b}$ \\
Sethoxydim & 2.47 & 0.72 & 0.37 & 0.71 & 0.07 \\
\hline LSD & & & &
\end{tabular}

Treatments with the same letter in a column are not significantly different at $\mathrm{p}<0.05$ as assessed by the LSD test

Table 8. Effect of various doses of herbicide on chlorophyll content, leaf number, plant height, shoot diameter, shoot fresh and dry weight, of Valeriana officinalis

\begin{tabular}{lccccc}
\hline $\begin{array}{c}\text { Rate of application } \\
{\left[\mathrm{mg} \text { a.i. } \cdot \mathrm{kg}^{-1}\right]}\end{array}$ & $\begin{array}{c}\text { Chlorophyll content } \\
{[\text { spad value] }}\end{array}$ & $\begin{array}{c}\text { Leaf number } \\
{[\mathrm{cm}]}\end{array}$ & $\begin{array}{c}\text { Shoot diameter } \\
{[\mathrm{cm}]}\end{array}$ & $\begin{array}{c}\text { Shoot fresh weight } \\
{[\mathrm{g}]}\end{array}$ & $\begin{array}{c}\text { Shoot dry weight } \\
{[\mathrm{g}]}\end{array}$ \\
\hline $0.75 \mathrm{X}$ (D1) & $21.2 \mathrm{a}$ & $5.0 \mathrm{a}$ & $2.0 \mathrm{a}$ & $9.3 \mathrm{a}$ & $0.93 \mathrm{a}$ \\
$1 \mathrm{X}$ (D2) & $20.8 \mathrm{ab}$ & $4.9 \mathrm{a}$ & $1.9 \mathrm{a}$ & $7.3 \mathrm{~b}$ & $0.76 \mathrm{~b}$ \\
$1.25 \mathrm{X}$ (D3) & $19.4 \mathrm{~b}$ & $4.6 \mathrm{a}$ & $1.8 \mathrm{a}$ & $6.6 \mathrm{c}$ & $0.69 \mathrm{c}$ \\
\hline LSD & 1.61 & 0.47 & 0.26 & 0.46 & 0.05 \\
\hline
\end{tabular}

Treatments with the same letter in a column are not significantly different at $\mathrm{p}<0.05$ as assessed by the LSD test

Table 9. Interactions of herbicides and their doses on chlorophyll content, leaf number, height, shoot diameter, shoot fresh and dry weight of Valeriana officinalis

\begin{tabular}{|c|c|c|c|c|c|c|}
\hline Treatment & $\begin{array}{l}\text { Rate of application } \\
{\left[\mathrm{mg} \text { a.i. } \cdot \mathrm{kg}^{-1}\right]}\end{array}$ & $\begin{array}{c}\text { Chlorophyll } \\
\text { content } \\
\text { [spad value] }\end{array}$ & $\begin{array}{l}\text { Leaf number } \\
\text { [plant] }\end{array}$ & $\begin{array}{l}\text { Shoot diameter } \\
{[\mathrm{cm}]}\end{array}$ & $\begin{array}{l}\text { Shoot fresh } \\
\text { weight } \\
\text { [g] }\end{array}$ & $\begin{array}{c}\text { Shoot dry } \\
\text { weight } \\
\text { [g] }\end{array}$ \\
\hline The control & - & $23.5 \mathrm{a}$ & $4.5 \mathrm{bcd}$ & $2.4 \mathrm{abc}$ & $10.6 \mathrm{bc}$ & $1.04 \mathrm{bcd}$ \\
\hline \multirow[t]{3}{*}{ Bentazon } & D1 & $20.6 \mathrm{abc}$ & $4.5 \mathrm{bcd}$ & $2.0 \mathrm{abc}$ & $7.8 \mathrm{f}$ & $0.73 \mathrm{gh}$ \\
\hline & D2 & $20.8 \mathrm{abc}$ & $4.2 \mathrm{~cd}$ & $2.0 \mathrm{abc}$ & $4.2 \mathrm{~h}$ & $0.43 \mathrm{i}$ \\
\hline & D3 & $18.3 \mathrm{bcd}$ & $4.0 \mathrm{~d}$ & $1.7 \mathrm{c}$ & $3.7 \mathrm{~h}$ & $0.38 \mathrm{i}$ \\
\hline \multirow[t]{3}{*}{ Oxadiargyl } & D1 & $21.9 \mathrm{ab}$ & $5.0 \mathrm{abcd}$ & $2.6 \mathrm{a}$ & $9.7 \mathrm{~cd}$ & $1.08 \mathrm{bc}$ \\
\hline & D2 & $24.3 \mathrm{a}$ & $5.0 \mathrm{abcd}$ & $2.0 \mathrm{abc}$ & $9.3 \mathrm{de}$ & 0.97 cde \\
\hline & D3 & 17.5 cde & $4.6 \mathrm{bcd}$ & $1.9 \mathrm{bc}$ & 8.4 ef & $0.91 \mathrm{ef}$ \\
\hline \multirow[t]{3}{*}{ Oxadiazon } & D1 & $24.0 \mathrm{a}$ & $5.3 \mathrm{abc}$ & $1.7 \mathrm{c}$ & 8.9 def & 0.95 cdef \\
\hline & D2 & $18.9 \mathrm{bcd}$ & $5.6 \mathrm{ab}$ & $1.8 \mathrm{bc}$ & $8.0 \mathrm{f}$ & $0.82 \mathrm{fgh}$ \\
\hline & D3 & $20.9 \mathrm{abc}$ & $4.8 \mathrm{abcd}$ & $1.8 \mathrm{bc}$ & $8.0 \mathrm{f}$ & 0.84 efg \\
\hline \multirow[t]{3}{*}{ Oxyfluorfen } & D1 & 15.3 de & $4.6 \mathrm{bcd}$ & $1.5 \mathrm{c}$ & $3.6 \mathrm{~h}$ & $0.34 \mathrm{ij}$ \\
\hline & D2 & $18.3 \mathrm{bcd}$ & $4.5 \mathrm{bcd}$ & $1.6 \mathrm{c}$ & $2.0 \mathrm{i}$ & $0.21 \mathrm{jk}$ \\
\hline & D3 & $13.6 \mathrm{e}$ & $4.0 \mathrm{~d}$ & $1.5 \mathrm{c}$ & $1.0 \mathrm{i}$ & $0.13 \mathrm{k}$ \\
\hline \multirow[t]{3}{*}{$\begin{array}{l}\text { Haloxyfop-R } \\
\text { (methyl ester) }\end{array}$} & D1 & $21.3 \mathrm{abc}$ & $6.0 \mathrm{a}$ & $1.8 \mathrm{bc}$ & $12.7 \mathrm{a}$ & $1.24 \mathrm{a}$ \\
\hline & D2 & $21.0 \mathrm{abc}$ & $5.6 \mathrm{ab}$ & $2.1 \mathrm{abc}$ & 8.9 def & 0.94 def \\
\hline & D3 & $21.2 \mathrm{abc}$ & $5.1 \mathrm{abcd}$ & $2.0 \mathrm{abc}$ & $8.1 \mathrm{ef}$ & 0.84 efg \\
\hline \multirow[t]{3}{*}{ Sethoxydim } & D1 & $21.5 \mathrm{abc}$ & $5.1 \mathrm{abcd}$ & $2.0 \mathrm{abc}$ & $11.7 \mathrm{ab}$ & $1.12 \mathrm{ab}$ \\
\hline & D2 & $18.8 \mathrm{bcd}$ & $5.0 \mathrm{abc}$ & $1.8 \mathrm{bc}$ & 8.3 ef & $0.90 \mathrm{ef}$ \\
\hline & D3 & $20.7 \mathrm{abc}$ & $5.5 \mathrm{ab}$ & $2.0 \mathrm{abc}$ & $6.5 \mathrm{~g}$ & $0.7 \mathrm{~h}$ \\
\hline LSD & - & 4.28 & 1.26 & 0.65 & 1.22 & 0.13 \\
\hline
\end{tabular}

Treatments with the same letter in a column are not significantly different at $\mathrm{p}<0.05$ as assessed by the LSD test 
Soltani et al. (2008) reported that application of bentazon once or twice at $840 \mathrm{~g} \cdot \mathrm{ha}^{-1}$ had no marked effect on the shoot weight of pinto bean. An increase in the above ground dry matter of winter wheat due to the good weed control from the sethoxydim application, was noted by Bidlack et al. (2006) as compared with the untreated control. Qasem and Foy (2006) reported that application of oxadiazon and oxyfluorfen increased shoot dry weight of Syrian marjoram L. Reduction in the chlorophyll content of sunflower, maize, and other plants by oxadiagryl application has been reported (Sandmann and Boger 1983; Nethra and Jagannath 2011).

\section{Conclusion}

The previous studies and ours suggest that the affects of the used herbicides depend on herbicide, herbicide rate, and plant species. The results of this experiment showed that oxadiargyl under all three rates, and that oxadiazon at the recommended dose and at $0.25 \%$ less than the recommended dose produced no significant symptoms of phytotoxicity or reduction of measured traits. The results also showed that haloxyfop- $\mathrm{R}$ and sethoxydim under all three rates, when used under similar conditions as those in this experiment, may be used safely for weed control in valerian.

\section{References}

Al-Khatib K., Claassen M.M., Stahlman P.W., Geier P.W., Regehr D.L., Duncan S.R., Heer W.F. 2003. Grain sorghum response to simulated drift from glufosinate, glyphosate, imazethapyr, and sethoxydim. Weed Technology 17 (2): 261-265.

Alebrahim M.T., Majd R., Rashed Mohassel M.H., Wilcockson S., Baghestani M.A., Ghorbani R., Kudsk P. 2012. Evaluating the efficacy of pre- and post-emergence herbicides for controlling Amaranthus retroflexus L. and Chenopodium album L. in potato. Crop Protection 42: 345-350.

Brecke B.J., Stephenson D.O., Unruh J.B. 2010. Timing of oxadiazon and quinclorac application on newly sprigged turfgrass species. Weed Technology 24 (1): 28-32.

Bidlack J.E., Middick A., Shantz D., MacKown C.T., Williams R.D., Rao S.C. 2006. Weed control in a pigeon pea-wheat cropping system. Field Crops Research 96 (1): 63-70.

Boger P., Wakabayashi K. 1995. Peroxidizing herbicides I: mechanism of action. Zeitschrift für Naturforschung 50c: 159-166.

Diebold S., Robinson D., Zandstra J., O'Sullivan J., Sikkema P.H. 2004. Sweet corn cultivar sensitivity to bentazon. Weed Technology 18 (4): 982-987.

Forcella F., Papiernik S.K., Gesch R.W. 2012. Postemergence herbicides for calendula. Weed Technology 26 (3): 566-569.

Kwiatkowski C. 2010. Evaluation of yield quality and weed infestation of common valerian (Valeriana officinalis L.) in dependence on weed control method and forecrop. Acta Agrobotanica 63 (2): 179-188.

Lamont G.P., Spohr L.J. 1988. Evaluation of oxadiazon and simazine for weed control and phytotoxicity in container-grown ornamental plants. Scientia Horticulturae 34 (1-2): 93-99.

Loken J.R., Hatterman-Valenti H.M. 2010. Multiple applications of reduced-rate herbicides for weed control in onion. Weed Technology 24 (2): 153-159.

Mine A., Miyakado M., Matsunaka S. 1975. The mechanism of bentazon selectivity. Pesticide Biochemistry and Physiology 5 (6): 566-574.

Nethra N.S., Jagannath S. 2011. Phytotoxic effect of oxadiargyl on germination and early growth of sunflower (Helianthus annuus L.) and maize (Zea mays L.). Archives of Phytopathology and Plant Protection 44 (19): 1901-1907.

Norsworthy J.K., Smith J.P., Meister C. 2007. Tolerance of directseeded green onions to herbicides applied before or after crop emergence. Weed Technology 21 (1): 119-123.

Pank F., Hannig H.J., Hauschild J., Zygmunt B. 1980. Chemical weed control in medicinal plant crops (Valeriana officinalis L.). Pharmazie 35 (2): 115-119.

Pavlivna Radchenko M., Mykhailivna Sychuk A., Yulievich Morderer Y. 2014. Decrease of the herbicide fenoxaprop phytotoxicity in drought conditions: the role of the antioxidant enzymatic system. Journal of Plant Protection Research 54 (4): 390-394.

Qasem J.R., Foy C.L. 2006. Selective weed control in syrian marjoram (Origanum syriacum) with oxadiazon and oxyfluorfen herbicides. Weed Technology 20 (3): 670-676.

Sandmann G., Boger P. 1983. Comparison of the bleaching activity of norf1uorazon and oxyfluorfen. Weed Science 31: 338-341.

Soltani N., Robinson D.E., Shropshire C., Sikkema P.H. 2006. Adzuki bean (Vigna angularis) responses to post-emergence herbicides. Crop Protection 25 (6): 613-617.

Soltani N., Nurse R.E., Robinson D.E., Sikkema P.H. 2008. Response of pinto and small red mexican bean to postemergence herbicides. Weed Technology 22 (1): 195-199.

Stoltenberg D.E., Gronwald J.W., Wyse D.L., Burton J.D., Somers D.A., Gengenbach B.G. 1989. Effect of sethoxydim and haloxyfop on acetyl-coenzyme A carboxylase activity in Festuca species. Weed Science 37 (4): 512-516.

Vencill W.K. 2002. Herbicide Handbook. 8th ed. Weed Science Society of America, Champaign, IL, USA, 493 pp.

Yousefi A.R., Rahimi M.R. 2014. Integration of soil-applied herbicides at the reduced rates with physical control for weed management in fennel (Foeniculum vulgare Mill.). Crop Protection 63: 107-112.

Zheljazkov V.D., Zhalnov I., Nedkov N.K. 2006. Herbicides for weed control in blessed thistle (Silybum marianum). Weed Technology 20 (4): 1030-1034. 